\title{
Gambaran sidik bibir mahasiswa pada Fakultas Kedokteran Gigi Universitas Hasanuddin (Lip print imaging of students at Faculty of Dentistry Hasanuddin University)
}

\author{
${ }^{1}$ Syamsiar Toppo, ${ }^{2}$ Irene Edith Rieuwpassa, ${ }^{3}$ J.I. Lisal, ${ }^{4}$ Ummi Salmiah Sari \\ ${ }^{1}$ Bagian Radiologi, Fakultas Kedokteran Gigi Universitas Hasanuddin, Makassar \\ ${ }^{2}$ Bagian Oral Biologi, Fakultas Kedokteran Gigi Universitas Hasanuddin, Makassar \\ ${ }^{3}$ Bagian Anatomi, Fakultas Kedokteran Universitas Hasanuddin, Makassar \\ ${ }^{4}$ Puskesmas Amparita, Sidrap \\ Indonesia
}

\begin{abstract}
Cheiloscopy is the study of lip print used to identify a person. Like finger print, lip print patterns recently are proven to have differences in each individual. Groove on the lip is fixed and cannot be changed. Following Suzuki method, lip print pattern is divided into 6 types, namely complete vertical groove, incomplete vertical groove, branched groove, groove intersected, groove reticular, and undifferianted. The purpose of this study was to determine the lip print pattern of Indonesian people, especially the students of the Faculty of Dentistry, University of Hasanuddin. This research was conducted at the Faculty of Dentistry, Hasanuddin University. Using random sampling technique, the sample of the study consisted of 50 subjects that include men and women in the age group 20-24 years. The lips that have been smeared with lipstick are open on its normal position, smile and the kiss is record. Masking tape is attached at various positions on the lips and then the tape is attached to the paper to be observed. Data are analysed with a magnifying glass and classified according to the "Classification Tsuchihashi and Suzukis. The study found all lip prints show different patterns. The pattern of lip prints is not only made up of only one type of groove, but appears as a mixture of various types. The pattern of lip prints is generally found in type II and type $V$ is the least found. The study concludes that no difference in the pattern of individual lip prints on a wide range of positions in the normal, open, smile and kiss positions.
\end{abstract}

Keywords: lip print, identification, students of Faculty of Dentistry Hasanuddin University

\begin{abstract}
ABSTRAK
Cheiloscopy adalah studi sidik bibir yang digunakan untuk mengidentifikasi seseorang. Seperti sidik jari, pola sidik bibir baru-baru ini terbukti memiliki perbedaan pada setiap individu. Alur pada bibir bersifat tetap dan tidak dapat berubah. Pola sidik bibir yang mengacu pada metode Suzuki membagi atas 6 tipe, yaitu groove vertical complete, groove vertical incomplete, groove branched, groove intersected, groove reticular, dan undifferianted. Penelitian ini dimaksudkan untuk mengetahui pola sidik bibir orang Indonesia, khususnya mahasiswa-mahasiswi di Fakultas Kedokteran Gigi Universitas Hasanuddin. Dengan menggunakan teknik random sampling, diperoleh 50 subjek yang meliputi pria dan wanita dalam kelompok usia 20-24 tahun. Bibir yang telah dioleskan lipstik pada posisi bibir dalam keadaan normal, posisi bibir terbuka, tersenyum, dan mengecup dicetak. Selotip ditempelkan pada bibir pada berbagai posisi, kemudian selotip tersebut dilekatkan pada kertas untuk diamati. Hasilnya dianalisis dengan menggunakan lup dan diklasifikasikan menurut Tsuchihashi and Suzuki's Classification. Ditemukan semua cetakan bibir menunjukkan pola yang berbeda. Pola sidik bibir tidak hanya terdiri dari satu jenis alur saja, tetapi muncul sebagai campuran dari berbagai tipe. Pola sidik bibir pada umumnya merupakan tipe II dan paling sedikit pada tipe V. Disimpulkan bahwa tidak ada perbedaan pola sidik bibir individu pada posisi normal, terbuka, tersenyum, dan mengecup.
\end{abstract}

Kata kunci: sidik bibir, identifikasi, mahasiswa Fakultas Kedokteran Gigi Universitas Hasanuddin

Koresponden: Irene Edith Rieuwpassa. E-mail: drgirene@yahoo.com

\section{PENDAHULUAN}

Saat ini, kualitas tindak kejahatan meningkat sehingga pihak berwajib sulit mengungkap identitas pelaku atau korbannya. Pelaku tindak kriminal coba mengelabuihukumdengan berusaha menghilangkan identitas yang khas pada tiap individu. Di Indonesia, penelitian tentang sidik bibir (lip print)masih sangat jarang, padahal pada kasus kriminal sering ditemui sidik bibir pada sendok, alat musik tiup, dan gelas. ${ }^{1}$

Kegunaan sidik bibir pertamakali dipublikasikan pada awal tahun 1932 oleh Edman Locard, sebagai salah satu karya ahli kriminal bangsa Perancis. Pada tahun 1975 telah dilakukan penelitian sidik bibir yang direkam dalam studi dari dasar variasi dan genetik dari pola ridge dari daerah membran mukosa bibir. Telah diteliti bahwa pola percabangan lebih banyak ditemukan pada bibir atas dan pola yang sederhana nampak pada bibir bawah., ${ }^{2,3}$

Bibir sebagai jaringan lunak dari rongga mulut dapat membantu mengidentifikasi individu. Struktur anatomi seperti rugae, pigmentasi, serta sidik bibir adalah konstan. Oleh karenanya data tersebut dapat 
dimasukkan ke dalam rekaman antemortem. ${ }^{2}$

Sidik bibir diketahui dalam ilmu forensik untuk membedakan seorang individu dibanding individu lain, sebagaimana dengan sidik jari.Pergerakan bibir membantu identifikasi yang berkenaan dengan suara. Bentuk bibir dapat digunakan sebagai pembuktian keaslian sesorang. Sidik bibir merupakan garis atau bentuk fissure yang normal dari bentuk kerutan dan kedalaman yang terlihat pada aspek zona transisi bibir manusia antara mukosa labial di bagian dalam dan kulit terluar. ${ }^{2,45}$

Sekarang ini ilmuwan memiliki sebutan untuk sidik bibir, yaitu cheiloscopy. Sidik bibir adalah sesuatu yang unik dan umumnya tidak mengalami perubahan selama hidup, walaupun terdapat beberapa jenis pola sidik bibir. ${ }^{4,5}$ Suzuki dan Tsuchihashi ${ }^{4}$ telah membagi sidik bibir menjadi 6jenis sidik serta lebih memilih bilangan Romawi untuk menandai jenisnya, yaitu jenis I memperlihatkan sebuah bibir dengan potongan groove yang bersih dan berjalan vertikal sepanjang bibir. Variasi jenis I,yaitu jenis I' memiliki panjang groove yang parsial dan garis-garisnya tidak semua menutupi keseluruhan permukaan bibir, tetapi garis tersebut hampir sama dengan jenis I. Jika jenis II memperlihatkan groove yang luas; jenis III malah memperlihatkan groove yang terbagi-bagi; jenis IV memperlihatkan pola retikuler; dan terakhir jenis $\mathrm{V}$ memperlihatkan pola yang lainnya, termasuk pola tak beraturan yang tidak terklasifikasi.

Untuk memudahkan pengamatan pola sidik bibir, maka bibir atas dan bawah dibagi menjadi 8 kuadran.

Penelitian ini dilakukan untuk mengetahui pola gambaran pemetaan sidik bibir pada posisi normal, terbuka, tersenyum dan mengecup.

\section{BAHAN DAN METODE}

Penelitian observasional ini, dilakukan pada 50 mahasiswa Fakultas Kedokteran Gigi Universitas Hasanuddin, Makassar dengan kriteria sampel yang tidak pernah mengalami trauma yang merusak pola anatomi bibir, subjek berasal dari ras yang sama,dan bersedia ikut dalam penelitian.

Setelah dilakukan pemilihan sampel sesuai yang kriteria, kemudian sampel diminta mengatur posisi bibirnya dalam keadaan normal dengan posisi bibir atas bertemu dengan bibir bawah, lalu lipstik yang berwarna merah dioles menggunakan kuas pada bibir sampel. Sambil sampel diinstruksikan untuk tetap mempertahankan posisi bibirnya,dilanjutkan dengan menempelkan selotip transparan pada bibir yang telah diolesi lipstik, kemudian selotip dilekatkan pada kertas.

Setelah selotip transparan dilekatkan pada kertas, lalu cetakan bibir atas dan bawah dibagi menjadi 8 kuadran dengan cara menarik garis horisontal dan garis vertikal 1 , garis vertikal 2 , dan garis vertikal 3 serta diamati pola sidik bibirnya menurut metode Suzuki. Prosedur serupa diulang dengan posisi bibir terbuka, tersenyum, dan mengecup.

\section{HASIL}

Berdasar penelitian mengenai pola sidik bibir mahasiswa FKG Unhas, diperolehlah pola sidik bibir posisi normal (tabel 1), terbuka (tabel 2), tersenyum (tabel 3), dan mengecup (tabel 4). Selanjutnya pada tabel 5 tampak uji-t perbandingan jumlah pola sidik bibir yang sama pada posisi normal dan tersenyum, dan tabel 6 adalah uji-t perbandingan jumlah pola sidik bibir yang sama saat normal dan tersenyum.

Tabel 1 Pola sidik bibir posisi normal

\begin{tabular}{|c|c|c|c|c|c|c|c|c|c|}
\hline \multirow{2}{*}{$\begin{array}{l}\text { Jenis sidik } \\
\text { bibir }\end{array}$} & \multicolumn{8}{|c|}{ Jumlah setiap jenis pola sidik bibir } & \multirow{2}{*}{ Total } \\
\hline & K1 & $\mathrm{K} 2$ & K3 & $\mathrm{K} 4$ & K5 & K6 & K7 & K9 & \\
\hline I & 17 & 13 & 17 & 11 & 7 & 26 & 16 & 6 & 113 \\
\hline I' & 3 & 2 & 0 & 1 & 0 & 3 & 3 & 1 & 13 \\
\hline II & 24 & 7 & 7 & 31 & 40 & 6 & 16 & 37 & 168 \\
\hline III & 3 & 3 & 0 & 2 & 1 & 1 & 2 & 4 & 16 \\
\hline IV & 1 & 22 & 26 & 4 & 2 & 14 & 13 & 2 & 84 \\
\hline $\mathrm{V}$ & 2 & 3 & 0 & 1 & 0 & 0 & 0 & 0 & 6 \\
\hline Total & 50 & 50 & 50 & 50 & 50 & 50 & 50 & 50 & 400 \\
\hline
\end{tabular}

Tabel 2 Pola sidik bibir posisi terbuka

\begin{tabular}{|c|c|c|c|c|c|c|c|c|c|}
\hline \multirow{2}{*}{$\begin{array}{l}\text { Jenis sidik } \\
\text { bibir }\end{array}$} & \multicolumn{8}{|c|}{ Jumlah setiap jenis pola sidik bibir } & \multirow{2}{*}{ Total } \\
\hline & K1 & $\mathrm{K} 2$ & K3 & $\mathrm{K} 4$ & K5 & K6 & K7 & K9 & \\
\hline I & 17 & 13 & 17 & 11 & 7 & 26 & 16 & 6 & 113 \\
\hline I' & 3 & 2 & 0 & 1 & 0 & 3 & 3 & 1 & 13 \\
\hline II & 24 & 7 & 7 & 31 & 40 & 6 & 16 & 37 & 168 \\
\hline III & 3 & 3 & 0 & 2 & 1 & 1 & 2 & 4 & 16 \\
\hline IV & 1 & 22 & 26 & 4 & 2 & 14 & 13 & 2 & 84 \\
\hline V & 2 & 3 & 0 & 1 & 0 & 0 & 0 & 0 & 6 \\
\hline Total & 50 & 50 & 50 & 50 & 50 & 50 & 50 & 50 & 400 \\
\hline
\end{tabular}


Tabel 3 Pola sidik bibir posisi tersenyum

\begin{tabular}{cccccccccc}
\hline \multirow{2}{*}{$\begin{array}{c}\text { Jenis sidik } \\
\text { bibir }\end{array}$} & K1 & K2 & K3 & K4 & K5 & K6 & K7 & K9 & \multirow{2}{*}{ Total } \\
\hline & I & 12 & 17 & 11 & 7 & 26 & 16 & 6 & 112 \\
I' & 3 & 2 & 0 & 1 & 0 & 1 & 3 & 1 & 11 \\
II & 24 & 7 & 6 & 31 & 40 & 6 & 16 & 37 & 168 \\
III & 3 & 3 & 0 & 2 & 1 & 1 & 2 & 4 & 16 \\
IV & 1 & 23 & 27 & 4 & 2 & 16 & 13 & 2 & 88 \\
V & 2 & 3 & 0 & 1 & 0 & 0 & 0 & 0 & 6 \\
\hline Total & 50 & 50 & 50 & 50 & 50 & 50 & 50 & 50 & 400 \\
\hline
\end{tabular}

Tabel 4 Pola sidik bibir posisi mengecup

\begin{tabular}{cccccccccc}
\hline \multirow{2}{*}{$\begin{array}{c}\text { Jenis sidik } \\
\text { bibir }\end{array}$} & K1 & K2 & K3 & K4 & K5 & K6 & K7 & K9 & Total \\
\cline { 2 - 8 } & 24 & 28 & 31 & 18 & 8 & 37 & 29 & 8 & 183 \\
I & 3 & 4 & 1 & 3 & 0 & 0 & 1 & 0 & 12 \\
I' & 22 & 9 & 6 & 28 & 39 & 5 & 14 & 39 & 162 \\
II & 0 & 0 & 0 & 1 & 1 & 1 & 1 & 3 & 7 \\
III & 0 & 8 & 12 & 0 & 2 & 7 & 5 & 0 & 34 \\
IV & 1 & 1 & 0 & 0 & 0 & 0 & 0 & 0 & 2 \\
V & 50 & 50 & 50 & 50 & 50 & 50 & 50 & 50 & 400 \\
\hline Total & & &
\end{tabular}

Tabel 5 Uji-t perbandingan jumlah pola sidik bibir yang sama pada posisi normal dan tersenyum

\begin{tabular}{cccc} 
Posisi Mulut & Jumlah Mahasiswa & Std. Deviation & Sig. (2tailed) \\
Normal & 50 & 10,405 & 1 \\
Tersenyum & 44 & 10,519 & 1 \\
\hline
\end{tabular}

Tabel 6 Uji-t perbandingan jumlah pola sidik bibir yang sama pada posisi normal dan mengecup

\begin{tabular}{cccc}
\hline Posisi Mulut & Jumlah Mahasiswa & Std. Deviation & Sig. (2tailed) \\
Normal & 50 & 10,405 & 1 \\
Tersenyum & 44 & 10,881 & 1 \\
\hline
\end{tabular}

\section{PEMBAHASAN}

Berdasarkan hasil penelitian yang mengacu pada metode Suzuki, ${ }^{4}$ diperoleh gambaran bahwa pola sidik bibir mahasiswa FKG Unhas pada umumnya terdapat pada jenis II, yaitu sebanyak 168(42\%) dan pola sidik bibir yang paling jarang terlihat pada adalah tipe $\mathrm{V}$ sebanyak $6(1,5 \%)$.

Tabel 1 dan 2 menunjukkan bahwa pada posisi normal dan terbuka ada persamaan pola sidik bibir tiap individu di 8 kuadran. Hal ini terjadi karena pada posisi normal maupun terbuka, otot-otot mulut dan wajah terhadap bibir itu sama secara horisontal dan vertikal. Hal ini sesuai dengan penelitian yang telah dilakukan oleh Juniastuti dan Sutisna ${ }^{1}$ yang menunjukkan bahwa pola sidik bibir individu tidak berbeda pada posisi normal dan terbuka.

Dalam keadaan tersenyum bila dibandingkan dengan keadaan normal (tabel3), ada perbedaan jenis pola sidik bibir pada 6 orang mahasiswa. Namun demikian uji-t menunjukkan nilai $p>0,05(1,00)$ yang artinya tidak ada perbedaan yang bermakna pada posisi tersenyum.

Mengenai pola sidik bibir posisi mengecup,pada tabel 4 tampak bahwa terdapat 6 orang mahasiswa yang mempunyai persamaan dengan pola sidik bibir normal dan 44 mahasiswa yang lain menunjukkan perbedaan pada tiap kuadran. Hasil uji-t tampak pada tabel 6 dengan nilai $p>0,05(1,00)$ menunjukkan tidak ada perbedaan yang bermakna antara pola sidik bibir yang normal dan mengecup.

Berbeda dengan penelitian sebelumnya yang dilakukan oleh Juniatuti dan Sutisna, bahwa pada saat bibir dalam posisi mengecup hampir semua individu berbeda pola sidik bibirnya pada tiap kuadran. Pada posisi ini telah diteliti bahwa pola vertikal melintasi bibir lebih banyak dibandingkan dengan pola-pola lainnya. Pada saat bibir mengecup, jenis yang paling sering muncul adalah jenis I dan yang paling jarang adalah jenis $\mathrm{V}$, karena kontraksi otot-otot bibir yang tertarik ke arah garis tengah bibir bibir sehingga groove-groove horisontal tidak dapat diamati. ${ }^{1}$

Berdasarkan hasil penelitian, disimpulkan bahwa gambaran jenis pola sidik bibir pada posisi normal, terbuka dan tersenyum pada umumnya tergolong pada jenis II di tiap kuadran dan yang paling sedikit terdapat pada jenis V. Sedangkan jika pada posisi mengecup paling banyak tergolong padajenis I, tetapi yang paling sedikit padajenis V.Meskipuntidak ada 
perbedaan pola sidik bibir individu pada posisi yang normal, terbuka, dan tersenyum, namun pada posisi mengecup ada 6 orang mahasiswa yang sama di tiap kuadrannya. Tipe pola sidik bibir spesifik untuk tiap individu dan berguna sebagai data tambahan untuk identifikasi individu.

\section{DAFTAR PUSTAKA}

1. Juniastuti M, Sutisna I. Perbandingan pola sidik bibir posisi normal dengan posisi terbuka, tersenyum dan mengecup. Indonesian J Dent 2005; 12 (2): 100.

2. Datta P, Sood S, Sabarwal JR. Cheiloscopy as a tool for human identification. Indian J Forensic Odontol 2012; 5: 1723

3. Patil D, Mugadlimathn AB, Hiremath R. A study on lip print types among North Karnataka people. Int J Biomed Adv Res 2013; 4 (9).

4. Suzuki K, Tsuchihashi Y. A new attempt of personal identification by means of lip print. Can Soc Forensic Sci 1971; 4: $154-8$

5. Bindal U, Jethani SL, Mehrotra N. Lip print as a method of identification in human beings. J Anat Soc India 2009 ; 9 (2): 152-5. 